\title{
A Comparative Study of the Effect of Humor on Grammatical Competence
}

\author{
Dana Al-Sudairi, MA \\ Lecturer at the department of English Language and Literature \\ College of Arts \\ King Saud University \\ Saudi Arabia
}

\begin{abstract}
The present study aims to assess the effectiveness of using humor in a grammar-based curriculum with Saudi female undergraduate students enrolled in a grammar course. The students were divided into a control group and an experimental group of about twenty-five students each. The experimental group studied English grammar with embedded humor in the lesson, and the control group studied according to the traditional structured approach. This study attempted to investigate whether there is a difference between the performance of students who had received humorous instruction and those who had not. The study utilized a pretest, cumulative posttest, and five weekly posttests that were administered to both groups. The results of this study showed that the grammatical competence of the experimental group was statistically positive when compared with the control group.
\end{abstract}

Keywords: humor in the classroom, second language teaching, grammatical competence

\section{Introduction}

Grammar is an essential skill which second language learners need to master in order to succeed in their studies. However, relying solely on the traditional methods of grammar instruction may not fulfill the current needs of global language learners. In order to be successful in teaching grammar, teachers must use effective tools to facilitate the learning process. Motivated by this realization, this study, therefore, seeks to investigate the effectiveness of one such language tool on students' grammatical competence. The introduction of humor has proven, over time, to be an instrument that coordinates well with teaching second language learners and enhancing the language learning process (Salehi \& Hesabi (2014), Hackathorn, 2011; and Skinner, 2010).In the past, teachers tended to avoid the use of humor in the classroom, especially when dealing with structurally-based curricula (Munoz-Basols, 2005). Most educators prior to the 1960s were hesitant to use humor in the classroom based on the norms of educational pedagogy of the era (Fleming, 1966). In the field of learning English as a foreign language, teachers preferred to use formal methods in teaching. In Fleming's era (1966) the idea of using humor in the classroom was not well received. His colleagues had difficulties getting the image of the teacher wielding the stick out of their minds. In the area of language teaching nowadays, teachers are constantly searching for new innovative tools to enhance learning in the classroom environment. They consider humor one of the modern language teaching tools, as it develops and encourages creativity and communicative skills in the target language (Munoz-Basols, 2005). Moreover, using humor facilitates learning and promotes a subconscious awareness of the target language (Tuncay, 2007). The literature on humor in education also shows that humor affects students physically by promoting positive physical changes (Caron, 2002) and psychologically as it reduces anxiety (Skinner, 2010).

This study is an attempt to investigate the effectiveness of humor in an academic setting. It aims to discover whether there is a difference between the performances of students who had received humorous instruction and those who had not. To this end, the following research questions were put forth:

1. Is the short-term grammatical competence of the students studying through humorous instruction better than that of the students studying through non-humorous instruction?

2. Is the long-term grammatical competence of the students studying through humorous instruction better than that of the students studying through non-humorous instruction? 


\section{Review of the Related Literature}

\subsection{Theoretical frameworks}

Perks' (2012) paper, "The Ancient Roots of Humor Theory", discusses the classification of humor theories introduced by the ancient philosophers which were: the superiority theory, the incongruity theory, and the relief theory. The superiority theory, according to Hobbes, who is considered one of the superiority attributors, is based on the idea that "humor arises from a 'sudden glory' felt when we recognize our supremacy over others" (Walte, 2007, p. 20). The early superiority theorists Plato and Aristotle emphasized that aggressive feelings fuel this type of humor (Walte, 2007). Additionally, they believed that when people use humor in a superior manner there will be psychological ramifications from this derisive amusement. Aristotle pointed out that derisive humor is an integral part of our daily communication. Yet, it must be realized that there is a time and place for different types of humor (Perks, 2012). It has also been noted that along with developing the feeling of supremacy, the other goal is to instill feelings of inferiority towards the target group (Walte, 2007). Perks (2012) stated that "humor has the potential to be a powerful tool of persuasion, but like any potent weapon, it should be used with caution" (p. 119). With this in mind, the use of derisive humor for instructional purposes is rarely acceptable (DeNune, 2005).

The most prominent theory of the three is the incongruity theory (Feagai, 2007), which is also known as the cognitive theory (Johnson, 1999). McGhee (1979) defined incongruity theory as "something unexpected, out of context, inappropriate, unreasonable, illogical, exaggerated and so forth" (p.10). Incongruity theory is based on the understanding that there is a surprise where an unexpected result occurs. Incongruent humor stretches the intelligence and provokes the imagination of an individual and "leaves the person searching for the answer to a riddle, or the gist of a punch line" (DeNune, 2005, p. 17). This theory is commonly used in many situations, whether it is intentional or not, such as in a teaching situation where there are many unexpected incidences of incongruous humor. The teacher may or may not intend to integrate humorous material or situations. The last theory, the relief/release theory, is based on the idea that "laughter gives us some temporary freedom from the numerous restrictions under which we live our daily lives" (Shade, 1996, p. 12). Freud believed that the energy released in laughter provides pleasure (Critchley, 2002). This type of humor is sometimes called 'black comedy', since the humor is about tragic situations like death and catastrophes (Breberg, $2009 \&$ DeNune, 2005). Thus, humor helps in getting rid of negative emotions and substitutes them with positive ones (Perks, 2012). In a classroom setting, this type of humor can be used to relieve tension and anxiety (DeNune, 2005).

\subsection{Perspectives}

In terms of the evolution of teaching, the use of humor is believed to be a relatively new concept. Teachers have historically not used or valued humor in teaching especially in higher education. It has become a more prevalent concept, and yet there is historical proof that integrating humor into the classroom goes back to possibly more than fifty years ago and is far from a novel idea. There was minimal documentation found, possibly due to it being a fairly new concept. Research has shown that this idea has been investigated as early as the mid nineteen sixties by Fleming (1966). He talked about not only using humor in the classroom but also adding a pictorial tool to support the written humor. However, Askildson (2005) states in his paper, that "humor has only recently taken its place as a fixture of classroom culture. Indeed, formal education was viewed as a wholly serious matter up until the mid-twentieth century" (p. 46). Even as late as the end of the twentieth century, Shade (1996) notes that society and in particular educational professionals do not agree with the role and value of humor in the classroom. Currently, however, it seems that more teachers tend to use humor as an instructional tool in their teaching. A number of studies have been conducted to determine the attitudes of teachers and students towards the implementation of humor in a college classroom.

Breberg (2009) interviewed ten female professors, who were from various teaching fields, of college level students in southwest Minnesota to determine their opinions towards using humor in the classroom. The instructors agreed that using humor in the classroom makes learning more fun and creates a number of positive effects for the students.

The focus of Mingzheng's (2012) study was to show that the use of humor could promote and improve teacherstudent relationship by lowering the affective filter in the foreign language classroom. He used a questionnaire to gage students' attitudes towards the use of humor in college classroom. Mingzheng (2012) described the process of learning English language by Chinese students in China as being a typical traditional English class which uses the grammar-focused, test-based and teacher-oriented method. This type of method leads to passive learning, which results in negative students' attitudes with a minimum of response.

208 
The researcher applied humor on Unit 8 of New Horizon College English, Book 3. At the end of the experiment with Unit 8 , the students were given a questionnaire. The results of the questionnaire highlighted the students' attitudes towards learning with humor. The students showed positive attitudes towards teachers using humor because it made memorizing their vocabulary easier and more interesting. It also helped them to learn the skills they needed better. The students also felt that using humor held their attention more and they wanted to participate more actively in the class.

\subsection{The effectiveness of humor on academic settings}

Humor can be an effective teaching tool to enhance the process of learning and information retention. In their study, Salehi \& Hesabi (2014) have applied planned humor on grammar curriculum on 60 female undergraduate students in Iran. The study was designed using two groups of subjects: a control group and a group that had humor inserted into their lectures. A pre-test was used to measure the students' grammatical knowledge before the experiment, an immediate posttest was administered to measure the short-term effects, and a delayed posttest was conducted to measure long-term effects of teaching grammar and for comparing the results with those of the immediate posttest. Their findings supported the idea that humor can have a significant impact on short and long term content retention.

The empirical study done by Hackathorn et al. (2011) examined the impact of humor on the performance of 51 students enrolled in a social psychology course. Randomized humor was used by the instructors throughout the semester. There was no pre-assigned humor applied to the constructs of the lectures, humor was applied naturally and spontaneously by the instructors. The teaching assistants used in this study performed their tasks from a blind standpoint to avoid bias. The assistants were used to observe humor by the instructors, note its success or failure and also develop six quizzes which were given approximately every three weeks. At the end of the semester, 24 concepts were measured based on the skill levels of knowledge, comprehension and application from Bloom's taxonomy. This study proved that students' scores on lectures taught with humor were higher than those without humor, and specifically the highest results were found at the comprehension level. It was also found that using humor at the application level did not increase learning. However, results from Manning (2002) contradict Hackathorn et al. (2011) in that humor is not useful beyond the knowledge and comprehension skill levels. His research has shown that humor is useful in understanding more difficult information and developing higher level thinking skills.

Mitchell (2005) conducted a study on 201 adult females enrolled in extension service classes using three delivery methods of humor. First, a cartoon was shown prior to the start of class, which was then followed by a humorous story about one third of the way through the class, and finally a humorous activity was done about two thirds of the way into the class. The instructor could also use humor incidentally. The results of her study showed that using humor made a significant difference in test scores and attention in the classroom. The qualitative measure of the interview supports the quantitative measure of the test given.

However, there are some studies that showed that there is little or no effect of using humor in teaching or testing situations. McMorris (1983) conducted a study on 126 students in eighth-grade English classes aimed at exploring the effects of humor on students' anxiety and test performance. He altered some test items using humorous texts and still maintained test validity. He also distributed a questionnaire to the students, and although there were no significant differences in performance results, most of the students perceived the jokes to be helpful and therefore they considered the test easier. Another study that failed to show a positive impact of humor in the academic setting was a four week study done by Mantooth (2010). The participants in his study were students from two undergraduate foundation education classes. The researcher gave lectures on two different topics in four separate lessons to four different groups using content-specific humor with the use of humorous pictures with comments. For the first lesson, humorous/nonhumorous content was randomly assigned. For the second lesson, each group was given a lecture in the opposite format. In the first week, the researcher introduced himself and the study. In the second week, before the start of class, the participants completed an interest survey, subsequently; they completed a domain knowledge pretest, then listened to a lecture, and finally, completed a post-lecture feedback survey. In week three, the second class was held. During this class, the participants took the posttest from the previous class and then proceeded to complete another interest survey, domain knowledge pretest and listened to a lecture. On the final visit in week four, the students were given the domain knowledge posttest and a student perception assessment scale. Although the findings were positive for using humor, they were not significant. 


\section{Method}

\subsection{Population of the study}

The population that was involved in this study was Saudi female EFL undergraduate students in the English Translation Department at the College of Languages and Translation, Princess Nora University, Riyadh, Saudi Arabia. They are relatively homogeneous in terms of their cultural backgrounds, gender, level of education and ages. Students are all Saudis and native speakers of Arabic. All students had a minimum of six years of EFL instruction, which included English instruction in grades 7 through 12. Upon entering college, students were enrolled in the university preparatory year program, which consists of 8 hours of English classes per week. The range of ages was between 18 and 20 years old.

In this study, the students were divided into a control group and an experimental group of twenty-five students each. Both groups were from the intact level 4 students enrolled in the Grammar -2- course as part of their fiveyear BA translation program. They are assigned to the same grammar textbook Understanding and Using English Grammar (4th ed.) by Azar (2009). The experimental group studied English grammar supported with the implementation of humor, and the control group studied according to the traditional method of teaching.

The study began with 60 students (30 students in each group). However, the number was reduced to 50 due to irregular attendance. Thus, students who were not attending regularly were excluded from the experiment. All participants took the Grammar -2- course for the first time, and no repeaters were included.

\subsection{Research design}

This study is considered a quasi-experimental research, because the researcher did not have control over who would be in each group, since it was not feasible to randomly assign each subject to a group. However, the groups were randomly selected from a pool of ten groups. The nonequivalent control group design was used in this study. As represented by Salkind (2009), table 1 shows what the nonequivalent control group design looks like (p. 243).

Table 1The nonequivalent control group design

\begin{tabular}{l|l|l|l|l}
\hline Step 1 & Step 2 & Step 3 & Step 4 \\
\hline $\begin{array}{l}\text { Participants are assigned to the } \\
\text { experimental group }\end{array}$ & $\begin{array}{l}\text { A pretest is } \\
\text { administered }\end{array}$ & $\begin{array}{l}\text { A treatment } \\
\text { administered }\end{array}$ & is $\begin{array}{l}\text { A posttest is } \\
\text { administered }\end{array}$ \\
\hline $\begin{array}{l}\text { Participants are assigned to the } \\
\text { control group }\end{array}$ & $\begin{array}{l}\text { A pretest is } \\
\text { administered }\end{array}$ & $\begin{array}{l}\text { No treatment } \\
\text { administered }\end{array}$ & $\begin{array}{l}\text { A posttest is } \\
\text { administered }\end{array}$ \\
\hline
\end{tabular}

Before applying the study, both groups were given a pretest to assess their grammatical competence of the first five chapters of the textbook Understanding and Using English Grammar (4th ed.) by Azar (2009) which were included in the course syllabus. The reason behind applying the pretest to the first part of the syllabus was to assure that the students in both groups were as comparable as possible in terms of their grammatical competence. The t- test was computed to determine if there were any statistically significant differences among the two groups' mean scores on the pretest measuring the first part of the syllabus. The results showed (Table 2) that there was no statistically significant difference revealed.

Table 2Mean averages of subjects' pretest scores out of 20

\begin{tabular}{llllllll}
\hline & Group & $\mathrm{N}$ & Mean & Std. Deviation & Std. Error Mean & $\mathrm{T}$ & sig. \\
\hline \multirow{2}{*}{ Pre-test (20) } & Control & 25 & 14.9600 & 2.10119 & .42024 & \multirow{2}{*}{1.453} & \multirow{2}{*}{0.153} \\
& Experimental & 25 & 14.0400 & 2.36696 & .47339 & & \\
\hline
\end{tabular}

Following the pretest assessment, humor was implemented on the experimental group for a period of 150 minutes weekly for five weeks. Concurrently, the control group was taught the Grammar -2- course without applying the treatment (i.e. humor). A weekly posttest (i.e. after each chapter) was given to both groups as well as a cumulative posttest at the end of the experiment to show to what extent the treatment benefited the students. The study lasted seven weeks according to the following schedule. 
Table 3Timetable of the study

\begin{tabular}{|l|l|l|l|}
\hline Week & Experimental group & Control group & Assessment \\
\hline Week 1 & No treatment & No treatment & $\begin{array}{l}\text { Cumulative pretest on the first part of the } \\
\text { curriculum that included the first five chapters }\end{array}$ \\
\hline Week 2 & Humorous tasks & No treatment & Test 1 on chapter 16 \\
\hline Week 3 & Humorous tasks & No treatment & Test 2 on chapter 17 \\
\hline Week 4 & Humorous tasks & No treatment & Test 3 on chapter 18 \\
\hline Week 5 & Humorous tasks & No treatment & Test 4 on chapter 19 \\
\hline Week 6 & Humorous tasks & No treatment & Test 5 on chapter 20 \\
\hline Week 7 & No treatment & No treatment & $\begin{array}{l}\text { Cumulative posttest on the second part of the } \\
\text { curriculum that included the last five chapters of the } \\
\text { curriculum }\end{array}$ \\
\hline
\end{tabular}

\subsection{Humorous material}

In this study, humorous materials were prepared by the researcher to coordinate with each section within each of the following five chapters: Coordinating Conjunctions, Adverb Clauses, Reduction of Adverb Clauses to Modifying Adverbial Phrases, Connectives that Express Cause and Effect, Contrast and Condition, and Conditional Sentences and Wishes. The instructional presentation was conducted through the use of Microsoft Office PowerPoint. Some materials were adapted from various resources such as Reader's Digest, 101 American English Riddles, etc. and others were self-designed. Jokes, puns, witticisms, riddles, and humorous videos were used as models to explain grammar rules (see appendix A). The purpose of using a variety of humorous materials with different contextual references was to maintain high interest, variety and relevance to the lessons. The contextual references used in this study pertained to educational, cultural, and everyday life situations. Some sentences were accompanied by humorous pictures or drawings to make the humor easier for the students to understand. Students in the experimental group were also asked to practice reading humorous sentences after each chapter, in order to apply the rules that they had just learned. Although the majority of the humor used in the classroom was planned, it should be recognized that the incidental use of impromptu humor did occur and was expanded upon where appropriate.

\subsection{Tests}

All subjects of the sample were given a pretest, five short-term posttests and a cumulative posttest as part of the research process. For the initial stage, the pretest used in this study was given to document the initial differences between the subjects' grammatical competence of the first part of the curriculum that included the first five chapters of their Grammar -2- course: Modals- Noun Clauses- Adjective Clauses- Gerunds and Infinitives 1Gerunds and Infinitives 2. The reason behind testing the student's performance on the first part of the curriculum was to be able to argue that any discrepancies between the subjects' performance by the end of the experiment was due to the treatment and not to any preexisting differences. Throughout the course of the study, weekly posttests were given to assess ongoing competencies. These ongoing assessments were designed to evaluate weekly progress. Both groups were evaluated weekly to provide a continuous comparison of their proficiency levels. At the end of the study, a cumulative posttest was given to compare the subjects' performance after the treatment. The cumulative posttest was given one week after the experiment and covered the same chapters that the weekly posttests included.

All tests in this study were designed using a similar question format which includes fill-in-the-blank, do as shown in parentheses, multiple choice, and error correction. The rationale behind the choice of more than one question format was based on the kinds of skills that needed to be assessed. It was determined that one question format did not adequately assess all grammatical components included in the course syllabus. Another important consideration in the choice of test format was that it paralleled the instructional question format of the curriculum, which included carefully chosen leveled vocabulary. All tests were categorized as objective tests since one answer was acceptable for each test item as shown in appendices B, C and D .The objective test format was chosen because it lent itself more readily to efficient and more reliable test scoring and statistical analysis.

\subsubsection{Test validity}

Test validity is vital which means that a test used in any study must measure what it is designed to do or intended to measure (Salkind, 2009). All tests utilized in this study can be said to have face and content validity. 
In reference to the pretest given, it assessed the prior knowledge base of the students from the previous five chapters of the text in the Grammar -2- course which were taught earlier in the semester. As for the posttests of this study, they were, in fact, designed to measure the subjects' performance on the following five chapters addressed in this study specified in the Grammar -2- course outline. Consequently, the pretest, the five short-term posttests, and the cumulative posttest were designed to test a particular area of knowledge.Test validity was ensured by three experienced grammar instructors at the college where the study was conducted. They made several editing suggestions such as, deleting selected items because the level of vocabulary within the items was too advanced, as well as rephrasing some of the instructions due to their complexity.

\subsubsection{Test reliability}

According to Salkind (2009), test reliability refers to the ability of the test scores to be stable over time. In this study, parallel-form reliability was calculated for the scores of two tests in order to determine test equivalence (i.e. how similarly they function). The pretest and the cumulative posttest were piloted with a sample $(\mathrm{n}=15)$ of students who had recently passed the Grammar -2- course one week before this study had begun at Princess Nora University where the study was conducted. It should be noted that the piloted sample was not involved in any way with the experiment. Both the pretest and the cumulative posttest were administered to the piloted sample, with a one-day interval between the two test administrations. The Pearson correlation coefficient was configured on the scores of the two measures taken by the same group of subjects. As shown in table (4), the Pearson correlation coefficient obtained from the analysis was 0.874 and the value of the Sig. (2-tailed) was 0.000. This result indicated that the participants' responses to the two instruments were reliable.

Table 4Reliability of Pearson correlation coefficient between pretest and posttest

\begin{tabular}{llll}
\hline & & Pre-test (20) & Post-test (20) \\
\hline \multirow{3}{*}{ Pre-test (20) } & Pearson Correlation & 1 & $.874^{* * * *}$ \\
& Sig. (2-tailed) & & .000 \\
& $\mathrm{~N}$ & 15 & 15 \\
\hline \multirow{3}{*}{ Post-test (20) } & Pearson Correlation & $.874^{* * * *}$ & 1 \\
& Sig. (2-tailed) & .000 & \\
& $\mathrm{~N}$ & 15 & 15 \\
\hline
\end{tabular}

\section{Data analysis and results}

\subsection{Testing question one}

Research question one poses: Is the short-term grammatical competence of the students studying through humorous instruction better than that of the students studying through non-humorous instruction? To answer the first question of this study, descriptive analyses as well as a series of $t$-tests for two independent samples were used to investigate any statistically significant differences in the weekly short-term test findings of the control and the experimental groups. Since the pretest yielded no significant difference between both groups at the beginning of the study (table 2), it was reasonable to consider that any significant differences in their mean scores on the following tests would be due to the experimental treatment. The following table presents the differences between the two groups for the five weekly tests.

Table 5Differences in mean scores for posttests 1-5 between the control and experimental groups

\begin{tabular}{|c|c|c|c|c|c|c|c|}
\hline Test & Group & $\mathbf{N}$ & Mean & $\begin{array}{l}\text { Std. } \\
\text { Deviation }\end{array}$ & $\begin{array}{l}\text { Std. Error } \\
\text { Mean }\end{array}$ & $\mathbf{T}$ & sig. \\
\hline \multirow{2}{*}{$\begin{array}{l}\text { Short-term } \\
\text { test } 1\end{array}$} & Control & 25 & 6.6600 & 2.25333 & .45067 & \multirow{2}{*}{-2.429} & \multirow{2}{*}{$0.019^{*}$} \\
\hline & Experimental & 25 & 8.0200 & 1.66132 & .33226 & & \\
\hline \multirow{2}{*}{$\begin{array}{l}\text { Short-term } \\
\text { test } 2\end{array}$} & Control & 25 & 6.7700 & 1.53928 & .30786 & \multirow{2}{*}{-2.023} & \multirow{2}{*}{$0.049^{*}$} \\
\hline & Experimental & 25 & 7.7400 & 1.83780 & .36756 & & \\
\hline \multirow{2}{*}{$\begin{array}{l}\text { Short-term } \\
\text { test } 3\end{array}$} & Control & 25 & 7.4000 & 2.30489 & .46098 & \multirow{2}{*}{-1.031} & \multirow{2}{*}{0.308} \\
\hline & Experimental & 25 & 7.9800 & 1.61038 & .32208 & & \\
\hline \multirow{2}{*}{$\begin{array}{l}\text { Short-term } \\
\text { test } 4\end{array}$} & Control & 25 & 7.1200 & 2.06801 & .41360 & \multirow{2}{*}{0.087} & \multirow{2}{*}{0.931} \\
\hline & Experimental & 25 & 7.0700 & 1.99937 & .39987 & & \\
\hline \multirow{2}{*}{$\begin{array}{l}\text { Short-term } \\
\text { test } 5\end{array}$} & Control & 25 & 6.7200 & 1.45115 & .29023 & \multirow{2}{*}{-4.101} & \multirow{2}{*}{$.000 * * *$} \\
\hline & Experimental & 25 & 8.2600 & 1.19129 & .23826 & & \\
\hline
\end{tabular}


As shown in table 5, the experimental group's mean scores surpassed the control group's mean scores except on posttests 3 and 4. Although the experimental group's mean scores were higher than the control group on posttest 3 , the value of significance was greater than .05 which indicates that the implementation of humor did not affect the students' performance on posttest 3. And for posttest 4, the control group's mean score was higher than the mean scores of the experimental group, but there was no statistical significance. On the other hand, the value of significance was smaller than .05 in posttests 1,2 and 5 which indicates that the experimental group performed better on posttests 1,2 , and 5 .

\subsection{Testing question two}

Research question two poses: Is the long-term grammatical competence of the students studying through humorous instruction better than that of the students studying through non-humorous instruction? To answer the second question of this study, the subjects' scores on the pre- and cumulative posttest in each group were analyzed using descriptive statistics as well as the $t$-test for two independent samples. Since the pretest yielded no significant difference between both groups at the beginning of the study (table 2), it was reasonable to consider that any significant differences in their mean scores on the posttest would be due to the experimental treatment. The following table presents the differences between the two groups for the cumulative posttest.

Table 6Differences in mean scores for cumulative posttest between the control and experimental groups

\begin{tabular}{|l|l|l|l|l|l|l|l|}
\hline Test & Group & $\mathrm{N}$ & Mean & Std. Deviation & Std. Error Mean & $\mathrm{T}$ & sig. \\
\hline \multirow{2}{*}{ Long-term Post-test (20) } & Control & 25 & 15.3400 & 2.33059 & .46612 & \multirow{2}{*}{-1.237} & \multirow{2}{*}{0.222} \\
\cline { 2 - 8 } & Experimental & 25 & 16.1100 & 2.06418 & .41284 & & \\
\hline
\end{tabular}

The table reveals that the subjects in the experimental group showed better performance on the cumulative posttest $($ mean $=16.11)$ than the subjects in the control group (mean=15.34). The $t$-test for independent samples was conducted to explore the impact of humor on the cumulative posttest. Although the subjects from the experimental group showed better performance on the cumulative posttest than the subjects from the control group, there was no statistically significant difference at the $\mathrm{p}<.05$ levels in scores for both groups (sig. $=0.222$ ).

\section{Summary and discussion of results}

The results of this study suggested that students who were taught through the implementation of humor performed better on weekly posttests than students in the control group. However, two of the five posttests did not show a significant difference between the scores of the control group and the experimental group.The results also suggested that students who were taught through the implementation of humor performed better on the cumulative posttest than students in the control group. Although the result was positive, it was not significantly so.

The findings are consistent with the findings of other studies conducted on the effects of humor on college level students, such as Salehi \& Hesabi (2014), Hackathorn et al. (2011), and Mitchell (2005). The findings of Salehi \& Hesabi (2014) support this study, that the inclusion of humorous tasks has a significant effect on the students' performance on a grammar curriculum compared to an unenhanced grammar curriculum. The instruments and data collection used are very similar to the current study. Unlike this study, which used planned humor, Hackathorn et al. (2011) applied spontaneous humor by the instructors to test the impact of humor on students' performance. Students in Hackathorn's et al. (2011) class were given quizzes at regular intervals throughout the semester which is similar to this study, in that a series of assessments were given throughout the semester. The concepts tested used the first three levels of Bloom's taxonomy. It should be noted that, although the assessment of these skill levels were not specifically stated in this study, they were, in fact, assessing similar skills of knowledge, comprehension and application as defined in Bloom' taxonomy. On the other hand, Mitchell (2005) used a variety of delivery methods of planned humor in the classroom. The results showed that the students taught with humor received significantly higher test scores on their cumulative test compared to the control group. However, the cumulative results were positive yet not significant in this study. The results of the three studies as well as this study support the theory that the use of humor has a positive effect on students' performance on test scores.

As presented in section (2.3.), there were two findings that failed to show a positive link between humor and test performance. McMorris (1983) applied humor on standardized grammar test items. These results cannot be compared with the results of this study, since humor was used as a teaching tool and not a testing tool. Mantooth (2010), on the other hand, used content-specific humor in a lecture as a teaching tool. 
The results of his study are partially similar to this study in that humor affected test scores positively but not significantly. It is possible that the brevity of Mantooth's (2010) experiment, which involved only two lectures, led to less significant results. However, as mentioned before, in this study test results were significant on all test scores except for weekly posttests 3 and 4 as well as the cumulative post-test when comparing the control group with the experimental group.

\section{References}

Askildson, L. (2005). Effects of humor in the language classroom: humor as a pedagogical tool in theory and practice. The Arizona Working Papers in Second Language Acquisition and Teaching, 12, 45-61.

Azar, B. S. \& Stacy, A. H. (2009).Understanding and Using English Grammar (Fourth Edition). US: Pearson Education.

Breberg, L. (2009). Female University Instructors' Use of Humor in the Classroom.M.S.E. dissertation, Southwest Minnesota State University. Retrieved from http://proquest.umi.com/

Caron, J. E. (2002). From ethology to aesthetics: Evolution as a theoretical paradigm for research on laughter, humor, and other comic phenomena. Humor: International Journal of Humor Research, 15 (3), 245-281.

Critchley, S. (2002).On Humor. London and New York: Routledge.

DeNune, S. G. (2005).A Look at the Importance of Humor in the Classroom. M.A.E. Dissertation, Pacific Lutheran University. Retrieved from http://proquest.umi.com/

Feagai, H. (2007). Humor in Higher Education Nursing Classrooms: Perspectives from Polynesia. Ed.D. dissertation, Argosy University. Retrieved from http://proquest.umi.com/

Fleming, G. (1966). Humor and language teaching.Audio-Visual Language Journal, 3 (3), 1-7.

Hackathorn, J. et al. (2011). All kidding aside: Humor increases learning at knowledge and comprehension levels. Journal of the scholarship of Teaching and Learning, 11 (3), 116-123

Johnson, D. M. (1999).The Psychology of Humor and Wit: From Banana Peels to Viagra Jokes. Santa Barbara, CA: Fithian Press.

Manning, K. I. (2002). Lighten Up! An Analysis of the Role of Humor as an Instructional Practice in the Urban and/or Culturally Diverse Middle School Classroom. A Doctor of Philosophy Dissertation, Cleveland State University. Retrieved from http://proquest.umi.com/

Mantooth, J. (2010). The Effects of Professor Humor on College Students' Attention and Retention. A Doctor of Philosophy Dissertation, Auburn University. Retrieved from http://proquest.umi.com/

McGhee, P. E. (1979). Humor: Its Origin and Development. San Francisco: W. H Freeman.

McMorris, et al. (1983). Effects of including humor in test items. Journal of Educational Measurement,22 (2), $147-155$.

Mingzhaeng, L. (2012). An empirical research on the application of humor in college English teaching. SocialBehavioral Sciences, 68 (4), 396-407.

Mitchell, L. S. (2005). Learning Through Laughter: A Study on the Use of Humor in Interactive Classrooms. A Doctor of Philosophy Dissertation, Mississippi State University. Retrieved from http://proquest.umi.com/

Munoz-Basols, J.(2005). Learning through humor: using humorous resources in the teaching of foreign languages. The ATIS Bulletin: 42-46.

Perks, L. G. (2012). The ancient roots of humor theory. Humor: International Journal of Humor Research, 25 (2), 119-132.

Salehi, F. \&Hesabi, A. (2014). Impact of teaching grammar through humor on Iranian EFL learners.Theories and Practice in Language Studies, 4(8), 1641-1652.

Salkind, N. J. (2009). Exploring Research (Seventh Edition). New Jersey: Pearson Education, Inc.

Schmitz, J. R. (2002). Humor as a pedagogical tool in foreign language and translation courses.Humor: International Journal of Humor Research, 15 (1), 89-113.

Shade, R. A. (1996).License to Laugh: Humor in the Classroom. Greenwood, CO: Libraries Unlimited, Inc.

Skinner, M. E. (2010). All joking aside: Five reasons to use humor in the classroom. The Education Digest www.eddigest.com, 19-21.

Tuncay, H. (2007). Welcome to hell: humor in English language learning. Retrieved from http://www.eric.ed.gov/

Walte, I. (2007). The American Way of Comedy - A Comprehensive Analysis of Humor on the Basis of the US sitcom 'friends'. M.A. dissertation. Germany: Grin Verlag. Retrieved from http://books.google.com/books 


\section{Appendix A}

Humorous PowerPoint Slides

Chapter 16: Coordinating conjunctions

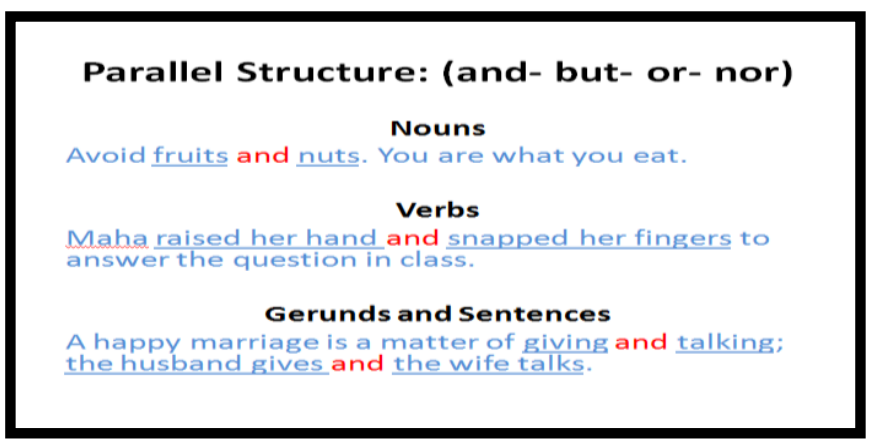

\section{Omitting repetition}

Marriage is not a word. Marriage is a sentence.

Marriage is not a word but a sentence.

\section{Exercise}

Join the sentences using a coordinating conjunction:

I'm not bald. I'm hairless. There is a difference

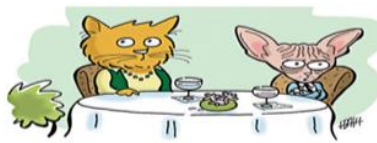

\section{Exercise}

Use commas:

It's a pacemaker for your heart. Plus, you can download your liver kidney lungs and pancreas.

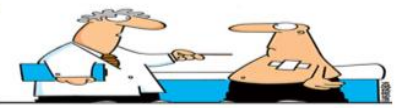

Separating independent clauses with periods; connecting them with and and but

run-on sentence

I stepped on a corn flake, now I am a cereal killer.

\section{Correct}

I stepped on a corn flake. Now I am a cereal killer.

I stepped on a corn flake, and now I am a cereal killer.

\section{Informal}

I stepped on a corn flake. And now I am a cereal killer.

\section{Parallel Structure: Using Commas}

Which are the most mathematical bugs?

Mosquitoes.

They subtract from pleasure, add to misery,

divide your attention, and multiply rapidly.

Paired conjunctions: correlative conjunctions

A guinea pig is neither from Guinea nor is it a pig.

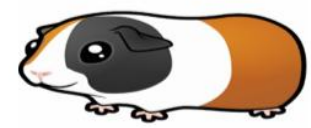

In a very short sentence

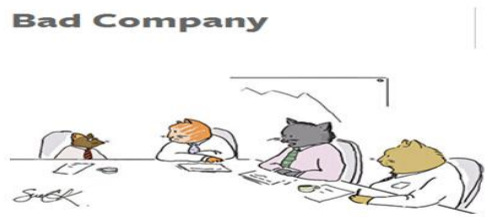

"Not to point fingers, but profits are down and we smell a rat" 
Chapter 17: Adverb Clauses

\section{Cause and effect: Because}

A noun and a verb were dating but they broke up because the noun was too possessive.

\section{Showing direct contrast: While}



Modern man has found it! "



\section{Whether or not / Even if}

Dear teacher,

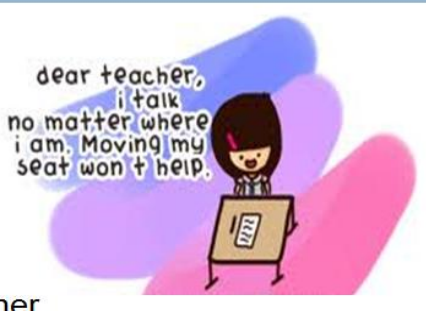

I talk in class whether or not you move my seat.

OR whether you move my seat or not
Do you have your cell phone with you?

If so, if you do, keep it out of sight. If not, if you don't, then no problem. 


\section{Even if}

Dear teacher,

I talk in class even if you move my seat.

\section{In case}

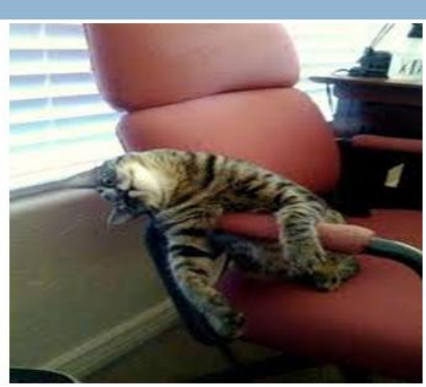

l'll be at my office in case you need me.

\section{Unless}

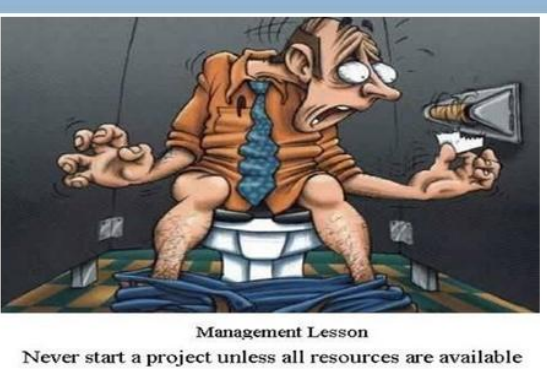

Never start a project if all resources are not available.

\section{Only lf}

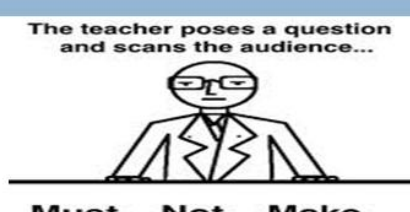

Must... Not... Make..

Eye... Contact.

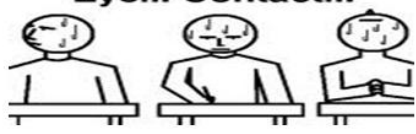

I will look at the teacher only if I know the answer. Only if I know the answer will / look at the teacher

Chapter 18: Reduction of adverb clauses to modifying adverbial phrases

\section{If there is a be form of the verb}

$\square$ While I was training to work at Coca Cola, I was given a pop quiz.

$\square$ While training to work at Coca Cola, I was given a pop quiz. $\square$ While the thief was stealing from a blood bank, he was caught red handed.

$\square$ While stealing from a blood bank, the thief was caught red handed. 


\section{When the adverb clause cannot be reduced to an adverb phrase}

$\square$ After the art attack in the museum, the science hall is now history.

$\square$ After attacking the museum, the science hall is now history. $X$ $\square$ After you miss math class, it starts adding up.

After missing math class, it starts adding up.

\section{Changing time clauses to modifying adverbial phrases}

$\square$ After I (had) Czeched the menu, I ordered Turkey.

$\square$ After Czech'ing the menu, I ordered Turkey.

After checking the menu, I ordered turkey.
Expressing the idea of "During the same time"

Teacher: Johnny, you know you can't sleep in my class.

Pupil: I know. But, maybe if you were just a little quieter, I could.

While dohnny was trying to sleep in class, he asked the teacher to be quieter.

\section{Expressing cause and effect in} modifying adverbial phrases

Teacher: What's the meaning of Attention Deficit Hyperactive Disorder?

Student: Bamba'lakkadi Jimba.

Teacher: I don't understand anything you said.

Student: Same here.

Because the student failed to answer the teacher's question, he tried to make fun of himself.

Failing to answer the teacher's question, the student tried to make fun of himself.
Teacher: How old is your dad

Student: $\mathrm{He}$ is as old as I am.

Teacher: How is it possible?

Student: Because he became a dad only after I was born.

Because my dad had become a dad only after I was born, he is as old as I am.

Having become a dad only after I was born, my dad is as old as I am. 
A noun and a verb were dating but they broke up because the noun was too possessive.

Because the noun was too possessive, it frightened the verb away.

Being too possessive, the noun frightened the verb away

\section{Using upon + -ing in modifying adverbial phrase}

$\square$ When William joined the army, he disliked the phrase 'fire at will'.

$\square$ Upon joining the army, William disliked the phrase 'fire at will'.

$\square$ On joining the army, William disliked the phrase 'fire at will'.

$\square$

Chapter 19: Connectives that Express Cause and Effect, Contrast and Condition

Woman without her man is nothing

Punctuation variations:

Woman, without her man, is nothing. Woman, without her, man is nothing. (Lyons, 2005)

\section{Warm up: The importance of} punctuation

Because the driver is never on time, he is always late.

Because of traffic, he is always late.

Due to traffic, he is always late.

Due to the fact that the driver is never on time, he is always late.

\section{Using Because of and Due tro}

Teacher: why are you always late?

Student: does it really matter? you still get paid.

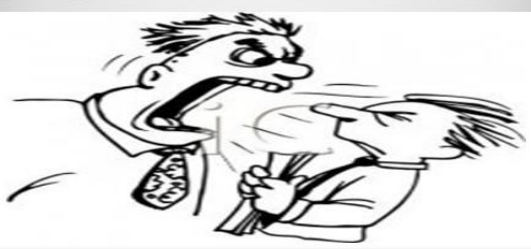

Using therefore, consequently and so

\section{Why did the chicken} cross the road?

I DREAM OF A

WETTER TOMOARROW...

CAN CROSS ROADS

AND NOT HAVE THEIR

QUITIVTION

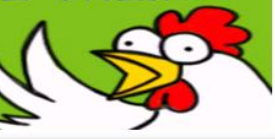


The chicken had to cross the road because it needed to get to the other side.

The chicken needed to get to the other side. Therefore, it had to cross the road.

The chicken needed to get to the other side. Consequently, it had to cross the road.

The chicken needed to get to the other side, so it had to cross the road.

\section{Such.o. That So .... That}

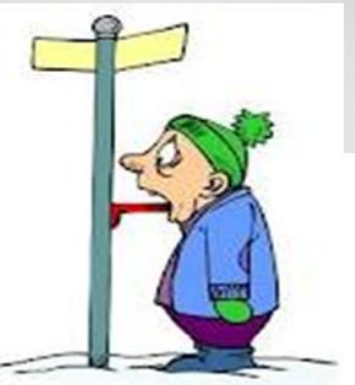

You speak so quietly that I can't hear you.

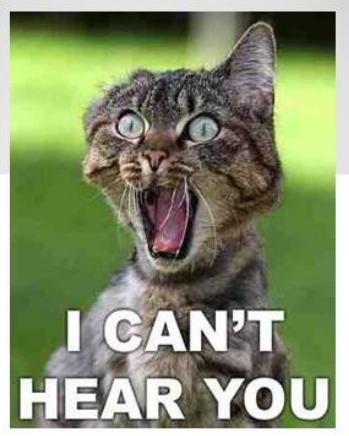

The chicken needed to get to the other side. Therefore, it had to cross the road.

The chicken needed to get to the other side. It had to cross the road, therefore.

The chicken needed to get to the other side. It, therefore, had to cross the road.

Because the weather was so cold, his tongue stuck to the frozen metal.

It was such cold weather that his tongue stuck

The weather was so cold (that) his tongue stuck to the frozen metal.
The students made so many mistakes that the teacher decided to hang this sign. 
Expressing purpose: using so that

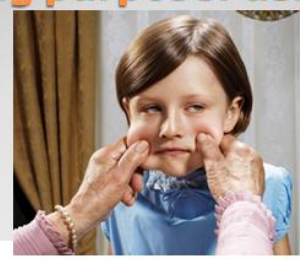

When I was young I didn't like going to weddings.

My grandmother would tell me, "You're next." However, she stopped doing that after I started saying the same thing to her at funerals.
I told my grandmother "you are next." in order to stop her from teasing me.

I told my grandmother "you are next." so that she would stop teasing me.

I'm going to tell my grandmother "you are next." so that she will stop teasing me.

The teacher is going to break the student's cell phone so that the students can focus.

The teacher broke the student's cell phone so that the students could focus.

The teacher breaks the student's cell phone so that he stops interrupting the class.

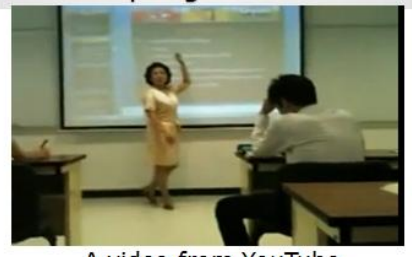

A video from YouTube

\section{Chapter 20: Conditional Sentences and Wishes}

$\begin{gathered}\text { True in the Present } \\ \text { and Future: }\end{gathered}$
$\begin{gathered}\text { Untrue in the } \\ \text { Present and Future: }\end{gathered}$
$\begin{gathered}\text { Teach } \\ \text { The act of texting, eating } \\ \text { and watching TV with an } \\ \text { open textbook nearby. }\end{gathered}$
$\begin{gathered}\text { a person who helps } \\ \text { you solve problems } \\ \text { you'd never have } \\ \text { without them. }\end{gathered}$
pass the exam.
If I were a teacher, I would
give everybody an A.

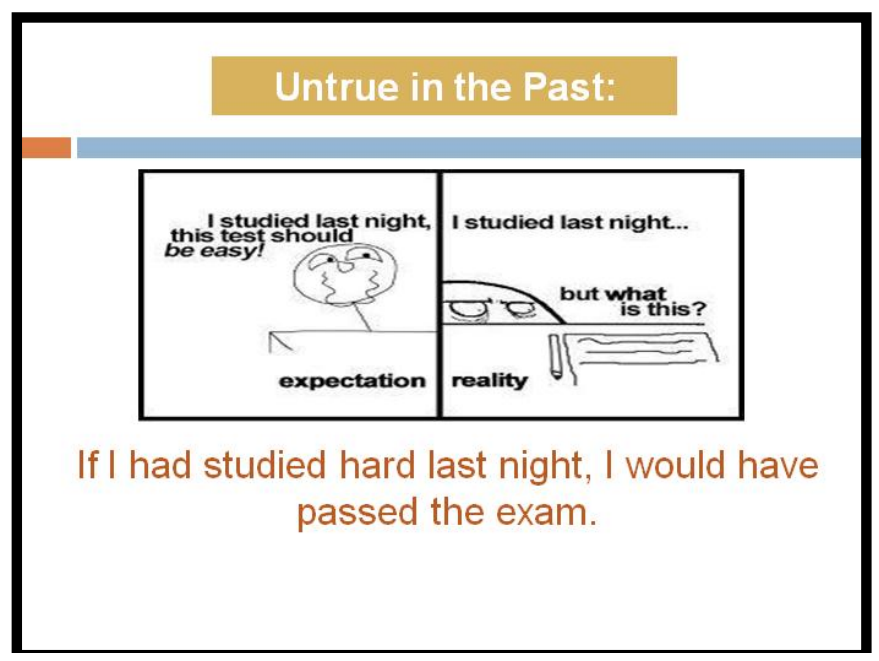


True in the Present and Future:

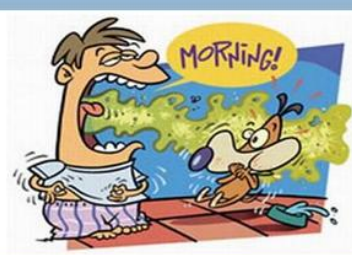

If I don't brush my teeth in the morning, I always have a bad breath.

True in the Present and Future:

An American in a British hospital asks the nurse:

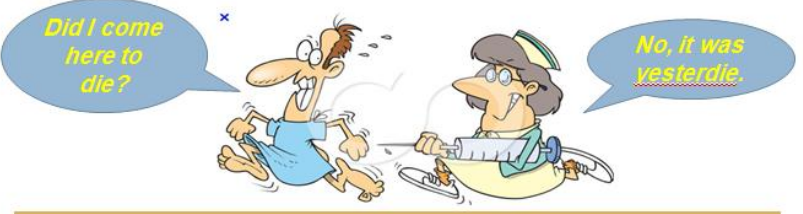

If a British person doesn't understand the American dialect, he misinterprets/ will misinterpret what the American says.

True in the Present and Future:

If you send a letter to the Philippines, put it in a Manila envelope.

Q: How do you make a horse fast?

A: If you want to make a horse fast, don't give him anything for a while.
True in the Present and Future:

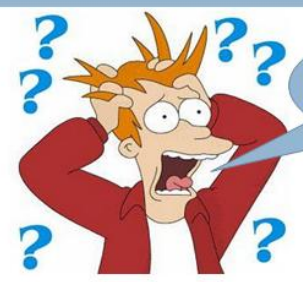

If I don't brush my teeth tomorrow morning, I will have bad breath.

True in the Present and Future:

A father was driving home with his young son. Suddenly the boy asked, "What is the meaning of the word 'drunk, 'Dad?" His father replied, "Look, there are two policemen standing over there. If I look at them and I see four policemen, then I should be drunk. "The boy said, "But, Dad, there's only one polliceman there!"

Untrue in the Present and Future

If a clock (have) ___ legs, time (run out.

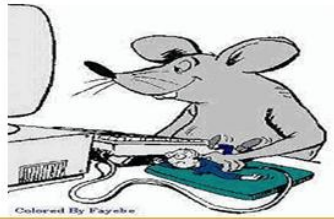

If a mouse (decide) to take revenge, he (use) a man as a computer mouse. 


\section{Untrue in the Past}



\section{Verb forms following WISH}



\section{Appendix B}

Pretest

\section{Complete each sentence with the correct form of the verb in parentheses. (4 points)}

1. Do you mind (help) me translate this article.

2. John plans (study) abroad next year.

3. My sister decided (go, not) ................ to the university tomorrow.

4. Nancy had a difficult time (find) . her car keys.

5. I'll never forget (meet) ............... the president when I was a child.

6. At the mall, I met my old English teacher. We stopped (talk) ............... for a while.

7. I would rather (go) ................ to the party last night.

8. I smell smoke. Something must (burn) ............... in the kitchen.

II. Complete each sentence with a preposition and a form of the verb in parentheses. (2 points)

1. They are very excited ........................... (go) to the museum.

2. She apologized .......................... (break) the vase.

\section{Correct the errors in the following sentences. ( 2 points)}

1. Joe is planning to go fish with his son next Monday.

2. I enjoyed the movie that you told me to watch it.

3. The book about that you told me is very interesting.

4. $\quad$ I talked to the students who their names are Nuha and Abeer.

\section{Follow the instructions in parentheses. ( 7 points)}

1. My young daughter wants to know where we are going to travel this year. (Underline the noun clause).

2. The boys who are playing in the yard are my cousins. (Reduce the adjective clause to an adjective phrase).

3. Coffee which is a common drink throughout the world is tasty. (Decide if the adjective clause is necessary or additional. If it is additional, add commas).

4. Is this information correct? (Change the question into a noun clause). I don't know

5. Where is the bus station? (Change the question into a noun clause). Do you know.

6. "I will arrive at noon", she said. (Change the quoted speech to a reported speech). 
She said

7. stop the clock shouted the referee we have an injured player (add punctuation and capitalization.)

\section{Choose the correct answer. (5 points)}

1. She told me that Nancy (might - should - will) arrive today, but she wasn't sure. She was just guessing.

2. My friend (could be sick - can't be sick - is sick). She just told me that she went to the hospital and got a sick leave.

3. Sara will (be able to/ can/ should) help you.

4. When I was a child, I (could hide - was hiding - would hide) in my bedroom every time I made my mother angry.

5. Why (can / can't / couldn't) all nations of the world just get along in peace?

6. The soup is too salty. You (must not have put / shouldn't have put / may not have put) so much salt in it.

7. (What he need/ what he needs/ what does he need) is a new job.

8. They will go (whoever/ whatever/ wherever) they want.

9. I saw two men, both of (whom/ which/they) are Chinese.

10. The students who did well in the exam were given prizes. This sentence means that:

a) (all students did well in the exam; all were given prizes).

b) (some students did well in the exam; some were given prizes).

\section{Appendix C}

Weekly Posttests

\section{Posttest 1}

\section{Circle the letter of the corret completion.}

1. Dan learned how to sing and___ at the Academy of the Arts.

$\begin{array}{lll}\text { a. dance } & \text { b. dancing conce }\end{array}$

2. Somebody called and __ up.
a. hung
b. hang
c. hanging

3. I admire him for his intelligence, cheerful disposition, and
a. he is honest
b. honesty
c. honest

\section{Correct the error in punctuation and capitalization.}

1. The café serves delicious pastries, coffee and ice cream but it is never crowded.

2. My brother is visiting me for a couple of days we spent yesterday together in the city and we had a really good time.

\section{Complete the sentences with the correct present tense from the verb in parentheses. \\ 1. Neither the students nor the teacher (know) ____ the answer. \\ 2. Both John and Ted (like) ____ to go cross-country skiing. \\ 3. Either Jack or Alice (have)_ the information you need. \\ 4. Not only my husband but also my children (realize) ____ that I have no idea what's going on in class.}

\section{Posttest 2}

\section{Circle the letter of the correct answer.}

1 By the time Ann leaves work today, she

a. will finish

2 When my aunt

a. arrived

3 I

b. will arrive the budget report.

c. will have finished

at the airport tomorrow, I'll be at work, so I can't pick her up.

c. arrives 

a. work
b. have worked
c. am working

4 a small rabbit ran across the path in front of me as I

a. had walked

b. was walking

c. am walking

trough the woods.

5 We won't go to the beach if it__ tomorrow.
a. rains
b. will rain
c. rained

$6 \quad$ While a crocodile has a very long, narrow V-shaped snout, the alligator's snout is
a. wider and U-shaped
b. long, narrow, and $\mathrm{V}$-shaped
c. large and green

\section{Follow the instructions.}

1. Mike got a grade of 98 percent because or even though)

2. Do you have enough money to go out to dinner?

If you don't have enough money, I'll pay for you. (Shorten the If-clause)

3. You can't get an A if you don't study very hard. (Rewrite the sentence using unless)

4. Even if you don't finish the exam, you should hand in your paper now. This sentence means that:

a) You don't have to hand in your paper if you don't finish.

b) You have to hand in your paper whether or not you finish

\section{Posttest 3}

I. Change the adverb clauses to modifying adverb phrases if possible.

1. Since he opened his new business, Bob has been working sixteen hours a day.

2. While Sam was driving to work, he had a flat tire.

3. Before Nick left on his trip, his son gave him a big hug and a kiss.

4. Because I had forgotten to bring a pencil to the examination, I had to borrow one.

\section{Rewrite the following sentence with the given word.}

When Sara received her acceptance letter for medical school, she shouted for joy.

Upon

\section{Posttest 4}

I. Do as shown between parentheses.

1. Because there was noise, I thought they were having a party. (Use due to and make all necessary changes)

2. Although the baby was hungry, he didn't drink the milk. (Rewrite the sentence using a conjunction. Make all the necessary changes)

3. Hind is very friendly and nice, while her sister is rude. (Rewrite the sentence using a transition. Make all the necessary changes) 
4. If I don't call my mother, she will start worrying about me. (Rewrite the sentence using a transition. Make all the necessary changes)

I must

II. Circle the letter of the correct completion.

1. The test was ___ easy that everyone got a high score.

a. such b. so

2. My wife turned off the radio, so that I
a. can
b. could
c. would get to sleep.

\section{Posttest 5}

1. Fill in the blanks with the correct form of the verbs in parentheses.

1 - If I am late, my teacher (get)....................angry.

2- $\quad$ If I (have) ...................free time, I would watch TV.

3- $\quad$ If I (be) ................. you, I would buy that red dress.

4- If you (listen) ................... to your mother's advice, none of this would have happened.

\section{Complete the sentences with an appropriate verb form.}

1. I have to tell her the truth, but I wish I

2. She didn't listen to her mother's advice, but she wishes she

\section{Follow the instructions in parentheses.}

If you should need more money, go to the bank before 6 o'clock.

(Make a sentence with the same meaning by omitting if).

\section{Appendix D}

Cumulative Posttest

\section{Choose the correct answer. (6 points)}

1. If I ------------ you, I would get some rest before the game tomorrow.
A) am
B) could be
C) were
D) had been

2. It looks like they are going to succeed ------------- their present difficulties.
A) despite
B) but
C) even though
D) yet

3. I talked to Ann throughout the evening, nothing I said changed her opinions.
A) yet
B)because
C) otherwise
D) so that

4. After -------to 45 minutes of an extremely boring speech, I found myself nodding off.
A) was listening
B) listen
C) listening
D) having listen

5. Erin likes to swim, jog, and ------------- tennis.
A) plays
B) play
C) played
D) playing

6. I ------- hard to help support my family ever since I was a child.
A) worked
B)work
C) am working
D) have worked

7. If I weren't working for an accounting firm, I ------------- in a bank.
A) work
B) will work
C) have worked
D) would be working

8. I wish you making the noise. It is bothering me.
A) would stop
B) are going to stop
C) stop
D) can stop

9. Our village had ------------ money available for education that the schools had to close.
A) so little
B) such little
C) so much
D) such much

10. Patience and are very important qualities in waiters.
A) polite
B) politeness
C) serious
D)seriously

11. Both my family and my neighbor .......... going camping this weekend. 

A) is
B) was
C)are
D)should

12. If you to your mother's advice, none of this would have happened.
A) have listened
B) are listening C) had listened D) listened

II. Write (I) if the sentence is incorrect. Write (C) if the sentence is correct. (2 points)

1-While taking a trip across Europe this summer, Jane's camera suddenly stop working.

2-After receiving the Nobel Peace Prize in 1979, Mother Teresa returned to Calcutta.

III. Punctuate the sentence properly, using periods and commas. Capitalize as appropriate.

(5 points)

1-Edward missed the final exam therefore he failed the test.

2- The waiter kept forgetting costumers' orders so he was fired .

3-Because we forgot to make a reservation we couldn't get a table at our favorite restaurant last night.

4-The lake was calm quiet and clear when Tom went fishing.

5-Tom went fishing because the lake was calm he caught two fish.

\section{Do as shown between brackets. (7 points)}

1. My registration was canceled. I didn't pay my fees on time (Combine the two sentences using the word (because).

2. I am going to the park unless it rains, doesn't rain. (Choose the correct word in italics.)

3. (The sun is not shining) I wish the sun ---------- right now. (Using the information in parenthesis, complete the sentence).

4. I will go only if I am invited. (Change the position of the adverb clause to the front of the sentence. Make any necessary changes).

5. They don't have a fridge in their apartment. They don't have a stove in their apartment. (Combine the sentences into one sentence that contains parallel structure by using neither...nor).

6. Do you like horror movies?

If you like horror movies, you can come watch one with us. (Shorten the If-clause)

7. She was really tired, but she still went to the meeting. (Express the same meaning of this sentence using another connective) 